\title{
Fructosamine Corrected for Total Protein Measurement
}

National Cancer Institute

\section{Source}

National Cancer Institute. Fructosamine Corrected for Total Protein Measurement. NCI Thesaurus. Code C161350.

The determination of the amount of fructosamine, corrected for total protein, present in a sample. 